\title{
Bollywood Remade: A Study on Umrao Jaan
}

\author{
Torsha Ghosh ${ }^{1^{*}}$ and Pooja Basnett ${ }^{*}$ \\ ${ }^{1} \mathrm{MBA}$ Student, Amity University, Noida, India \\ ${ }^{2}$ Assistant Professor, Department of Mass Communication, Sikkim University, India
}

*Corresponding author: poozas@hotmail.com

\begin{abstract}
Recreating the past is difficult, film makers barely succeed in replacing the memory of the past vision with their own. This research is based on a comparative study on the elements of both versions of the movie 'Umrao Jaan' and its social elements. This research solely investigates the social acceptance of the character of Umrao Jaan borrowing from both the movies - Umrao Jaan: 1981 and Umrao Jaan: 2006, drawing a distinct comparison of both eras and the evolution of the character. The research represents a critical analysis of Bollywood's visual interpretation of the character of Umrao Jaan. The idea is to portray the influence of visual culture over a social spectrum. This analysis highlights the social manipulation of the notions of the Indian women. The poetry and the songs from both the movies will be studied as symbolic elements that represent the shades of the character. The research defines the interpretation of the dilemma the character faces in the understanding of her dual identity as a courtesan and a woman. Even though Bollywood cultivates the ideal picture of a bold woman in the movie yet it fails to give it a new dimension. The research objectifies the reference of a puritan society as a symbol in the representation of the character in the movie. The element of beauty and femininity is studied as a complex association in the character's role and the industry's portrayal of the character. Romance is also studied as a major element that the movie has used to define the character.
\end{abstract}

Keywords: Bollywood, Character, Umrao Jaan, Comparison, Movie, Women, Social, Elements, Culture

The movie Umrao Jaan is an adaptation from the Urdu novel Umrao Jaan Ada written by Mirza Hadi Ruswa. This novel has be made into various movies over the years, in 1972 a Pakistani film director Hasan Tariq made Umrao Jaan Ada. In India it was first made in the name of Mehndi in 1958 by director S. M. Yusuf. Later in the year 1981 Umrao Jaan was directed by Muzaffar Ali and remade once again in 2006 by J. P. Dutta. However, this research paper only focuses on the representation of the character Umrao Jaan made in the year $1981 \& 2006$. The main objective of the research itself was to identify how Umrao Jaan was portrayed in 1981 \& 2006. This qualitative research is a comparative analysis of one character in two movies and is written in a narrative approach. The study focuses on various elements of women representation such as how the gaze of the women is shown. "Both male and female viewers look through this male gaze since the camera is constantly positioned in such a way. In this manner, women 'become the images of meaning rather than the maker of meaning" (Mulvey, 1975). This movies have also been a true example of what Mulvey say "Women are constantly looked at and displayed for the male spectator's pleasure".

\section{UMRAO JAAN (1981)}

Umrao Jaan, a movie by Muzzaffar Ali based on Lucknow in the nineteenth century. It was a time when various art forms reached its peak. The movie beautifully sketches 
out the portrayal of the time period; Urdu, mehfils, tawaifs, ghazals, shers, hookah's, dazzling dresses, beautiful houses and the kathak performances. The time is mostly represented by its glamour and art. The film goes as a ghazal on celluloid. Its musical flavour becomes the main channel of expression yet it does not go to any extremes to evoke pain or passion. Muzzaffar Ali keeps it controlled and light at the same time allowing the audience to sympathize with the character of Umrao Jaan. The movie notes the era of Sepoy Mutiny that gives it a historical significance. The music in the movie has a sensuous synchronization to its lyrics.

"Umrao Jaan did not create ripples among most critics when it was made because the story line revolving around a singer/ dancer who sells her body was an old concept for most Hindu/Urdu film-goers" (Jugu Abraham, 2002, IMDB).

\section{(a) The Portrayal of Courtesans}

The movie makes a bold effort to bring up the concept of courtesans, brothels and prostitution during that era. Sadly, a dark narrow lane that leads to a place where decent men do not go, a place reverberating with the beats of tabla and a bejewelled women dancing amongst men sitting around a hall -is the picture Bollywood has painted of a courtesan. However, the reality of many courtesans who lived in ancient and medieval India begs to differ. Some courtesans of the medieval era managed to make a mark in the male dominated society in those times. These women stood confident and aware of their abilities and did not hesitate to question the norm.

Some examples are; Lady Purasati, the lineage holder of the Mahasandhi instructions. Mahasandhi is a Sanskrit word that means 'the great perfection' in English and is a significant part of Tibetan Buddhism, which aims at no discrimination between caste, gender, and age to achieve the state of primordial being. She is respected for her knowledge and the songs she had written to spread amongst common men based on her beliefs.

Barani, on the other hand was much more than someone who just sang songs. She was known to be spiritually evolved and one who had enlightened herself on Buddhism under the lady Bodhi of Yakshini. She served as the master herself to the son of Bhibhi Rahula, the King of Kashmir and a Kashmiri scholar.

Even though Umrao Jaan as a movie makes a step to achieve a strong and bold female attention, it fails to add dimensions to the character of Umrao Jaan. The character has been culturally beautified with self made talents yet her ultimate goal has been the search for love. The movie very practically and hypocritically links beauty with love, where the song _'inn ankhon ki masti ke' by Asha Bhosle, goes as:

\section{Inn Aankhon ki maasti ke, mastaane hazaaron hain \\ Inn Ankhon ki maasti ke, mastaane hazaaron hain}

"There are thousands of men crazy for these intoxicating eyes, these eyes have spun a thousand tales"

\section{Ek tum hi nahi tanhaa, ultfat mein meri ruswaa iss sheher mein tum jaise deewaaney hazaaron hain}

"You are not the only one who has disgraced himself for my love, there are thousands like you in this city"

The song portrays that the character has won the hearts of many with her beauty and her enchanting eyes, yet the love is forbidden and is unacceptable to the society. Sadly even her beauty and her character are a disgrace and indirectly the reason for her tragic ending. The fact that she is beautiful has been taken into immense pride actively stating that it puts her ahead of all men who want her, beauty being her only confidence. The industry confuses itself relating boldness with sexuality timelessly, with wild representations of actresses in item numbers in the modern era.

"This is a film to be enjoyed by sight and sound- not merely at the level of the story" (Jugu Abraham, 2002).

\section{(b) The Portrayal of Women in Bollywood}

Social change is a complex emotion. It is gradual and unstructured and media is one of its best reflections. Bollywood is more than entertainment medium. It has far reaching impact on the mindsets of society at large. 
The representation of women is often used as a selling strategy in Bollywood films. The reflection of women on screen keeps changing time to time along with the changing trends in the continuously evolving social world, yet Bollywood has failed to free itself from the patriarchal undercurrents of the society. Women are time and again depicted and represented in a way that caters to the male gaze. Women are still categorized, the fact being achieved from song and dance sequences, through various forms of dressing and stereotypical images. Actresses are westernized, as is everything around them that has resulted in turning a woman into a commodity or an agent that needs to be made a spectacle so the film can sell well. Item dance numbers have ruled Bollywood timelessly. Bollywood sells itself with its item numbers. Item numbers sell sexuality as confidence. This hypocritical expression of vulgarity sold as entertainment is made to attract attention where influential actresses are made subject to attract public attention. Item numbers mostly have no relation to the plot of the movie yet they are used as vehicles towards commercial success that ensures repeated viewing. The word 'item' itself refers to an 'object'. Bollywood smartly pulls off the act of showing women their place by objectifying them as eye candies dressed in skimpy clothing, as a sole girl between lustful men, working their sexuality sensuously. This may serve as complete evidence that Bollywood believes that women dress in a certain way just to attract male attention. Item numbers have a vast history in Bollywood ranging from the time of Helen sizzling on screen in the song 'mehbooba, till date where Sunny Leone makes her fiery entry in the song 'Laila main Laila'. It is also made sure by Bollywood that the lyrics of these item numbers must not lose its authority to objectify women to satisfy male sexual gratification. Bollywood also makes sure in its representation in its item songs to make it seem like the character in the song 'wants it'.

Sadly, in the movie Umrao Jaan (1981), Bollywood represents the portrayal of the perfect picture of a woman robbed of self-respect, dignity and social justice, and her inability to do anything about it.

The film tells the tale of a 'tawaif' in a world of 'khotas' or parlours of prostitution of those days. The khotas were exclusive and cultured platforms of entertainment for selected patrons to imbibe in the elite beauty, culture and intellect, yet the word 'randi' has been used in the film to refer to the courtesans continuously.

Umrao Jaan has been portrayed as a romanticized character who suffers a great injustice from the society and for her disillusionment of love. The film portrays that women are just victims of circumstances. The traditional position of women in the society who are bound to accept their suppressing circumstances, play a major role in the movie.

The character undergoes shades of self definition. She comes as an object between men the first time she appears in front of nawab. The character evolves on account of the tragedies caused to her, yet in the end, she is left with only the understanding of her oppression and nothing more.

\section{UMRAO JAAN (2006)}

Umrao Jaan- 2006 has been a more romanticized version of the previous one starred by Aishwarya Rai and Abhishek Bachhan. The movie adopts the new generation attitude along with the technological improvisation. The character is acclaimed as a courtesan and poet who dreams of love and marriage. In the portrayal of a fragile, youthful character, the director has failed to compete with the previous, intellectual, edgy and mature character of Rekha.

The film, at first glance shows Umrao who has lived to tell her tragic tale sharing her story. The movie portrays the life and plight of courtesans, yet, a deeper reoccurring theme is the subjugation of women.

The story starts with Ameeran being kidnapped and sold by her uncle on account of a revenge on her father. She is treated as goods rather than human. She loses everything, including her name. Ameeran, now called Umrao is raised in a brothel to become a courtesan. On her first performance at the 'Nawab Sultan's mehfil' she finds herself in love with the Nawab who is enticed by her looks and then her poetry. Sultan manages an escape from the courtesan's life, for a non-stigmatized life of marriage and children. Her prodigious poetic talent is no more acknowledged the way a man's poetry would be- her growth as a poet is stopped, she finds herself 
trapped in a courtesans life and finds no way for escape or a turning point. Umrao is fought over, bargained and sold to men, which leaves her psyche an everlasting emotional damage. When sultan leaves Umrao, she accepts the suit of Faiz Ali (played by Sunil Shetty), a bandit. He leaves her monetary gifts to win her over, he also believes that she can be bought. Later in the movie Faiz Ali is killed and Umrao is left to make her own way. Finally in the end of the movie, after the war of independence strikes, Umrao's sudden encounter with her family takes an unpleasant turn where Umrao is driven away by her younger brother. During the confrontation, her mother is commanded by her brother asking her to let Umrao leave, for she will only bring shame to the family. It is seen that Umrao's mother is just as bound as she is in a cycle of women belonging to men and subjugating their desires for men.

The film shows a strong intention to highlight how Umrao Jaan has been let down by men, yet she keeps returning to them because they hold power over her life even though she has nothing left to lose.

Bollywood hypocritically glorifies beauty yet defines how even beauty may not work in one's favour.

The director of Umrao Jaan (2006), J.P Dutta's efforts to recreate the past has not been truly fruitful to the content of the viewers. Dutta's 'Umrao Jaan' continues further as a story from where the 1981 version ends, where Umrao returns to the brothel and is left all alone.

The overall approach of the movie has failed miserably taking into account the previous Umrao Jaan by Rekha.

\section{COMPARATIVE STUDY}

Though Umrao Jaan (2006) was not greatly successful, the film has entertained its viewers to a certain extent. Yet what is remarkable is that the director has shown the hostile but modern and innovative interference of the west into the primitive cultural practices in India. He shows a courageous Indian women (Khanum Jaan) protecting the girls of the brothel from the British forces.

The narratives of the films solely deal with identity and how identity may shift from one time to another. Part of both the movies feel like Bollywood has given the terms of a woman's responsibility towards self reflection. Some where it feels like Bollywood has boldly set women their limitations. The search for freedom has been the key portrayal in the movie yet the freedom is never given, that eventually results to the great tragedy.

Throughout the film (Umrao Jaan, 2006), there has been a notable focus on Umrao Jaan's eyes and her male visitors. This reflects the idea of a male gaze. The cinematographers use this element to force the audience to view her through the perspective of this male gaze that greatly objectifies the female presence. Umrao Jaan's character as a woman of desire was shown throughout the movie, and her mujra performances were greatly highlighted. The men surrounding her would be screaming 'vaha Umrao' to show their approval and amusement to her beauty, sexuality and her skills.

This objectification of women is also evidenced throughout countless films where women are 'undermined by lingering close-ups' of their curvy figures and tight clothes, all 'made to order for the male gaze' (Ross, 2006)

Her position in between men is notably objectified that makes her less of a woman and more of a lustful object. In this version of a movie unlike the previous one, Umrao was seen more as a seductress than a performer, here her intellectual dimension as a performer was lost, and she was rather seen as an object of desire. Also, the idea of Nawab Sultan paying her respect was later changed into hypocrisy on his shallow decision of changing his mind into marrying someone of his mother's choice. Nawab Sultan here has also been used as an agent who is bound as a social slave.

In Umrao Jaan (1981) Rekha has been framed beautifully. The character's beauty is her intelligence, maturity, self worth and her skill sets. Her face and her eyes subtly express the tragic journey from hope to despair, as she realises that she will never be free of the exigencies of her life. The disillusionment is never as vivid as the time when she sings 'yeh kya jagah hai doston?' Her eyes reveal her weariness and desolation like never before. Throughout the film she let her eyes do the talking, whereas, in Umrao Jaan (2006), the plot was made to look more exaggerated where in the process the maturity of 
the character was lost behind the dramatic eyes and heavy jewellery. The character portrayed the eyes of an enchanting seductress. The focus mostly remained on Aishwarya Rai's beauty. The performances were seen mostly as mujra's, even though both characters evolved with each performance, the character played by Aishwarya Rai failed to portray herself as an intelligent performer whereas Rekha displayed herself as art.

Both movies indirectly bring out Bollywood's sadistic approach to both characters of Umrao Jaan to portray them as women ruined under the suppression of circumstances. The movies could have had a better dimension and edge even without changing the story from the main novel. The portrayal of the character has been communicated lousily. More could have been expected from the remade version. The character could have come up as a more edgy, intelligent and emotionally strong character who knew how to deal with her circumstances and the price she had to pay. The character could have come up as a self governing entity and a tragic hero.

A notable reference of the film (Umrao Jaan 1981) is the part when Ameeran is sold at a lesser rate because she has dark complexion. The word 'sawli' is used for her. Even though the film tried to highlight a direct message referring to the Indian colour complex during that time indirectly questioning the preference of a fair complexion, the remake came up with flawless fair beauty instead. Even though the previous version added some intelligence to the concept of beauty, irrespective of colour, the remake destroyed the effort, along with all intellectual notions of beauty and the dimensions the previous film tried to portray.

In Aishwarya Rai's Umrao Jaan, the character is referred to as 'Tawaif' who is a highly sophisticated courtesan who catered to the nobility during the Mughal Era. In the previous (1981) version, in spite of the well versed soulful Urdu used in the film, in certain places the courtesans have been referred to 'Randi'- a word used as slang for prostitutes. It is debatable that in the mughal era, courtesans were seen as performers and meant more than just sex slaves, they were appreciated for their skills and their artistry, and maybe the unnecessary usage of the word 'randi' is not suitable for that time.

Woman to woman relationships have been given a lot of shades by the industry in this movie. The industry rightfully puts it forward that women of the same age only share the emotion of jealousy. Direct and indirect conflicts between Umrao and Bismillah have been put forward in the film and an unpleasant relationship of hidden jealousy between the two has been portrayed. Coming from Bollywood, it is not a strange phenomenon in the recent times as well. Bollywood never fails to hypocritically limit the characterizations of women in cheap orders. On the other hand the film has also portrayed the undefined bond between Khanum Jaan and other courtesans where she rightfully fights to protect her courtesans from the British forces.

The movie also portrays that the ultimate goal of a woman is to find love. Umrao Jaan is never seen as a person who deserves true love, in fact she is seen as an object that can be used and manipulated according to the social desires, as a woman. She faces betrayal from her family, from her friend, from her lover and therefore all her ideas of love are destroyed that leads to her ultimate destruction. The film could have portrayed her as a self made woman of experience who ultimately chooses to survive the life she has been given in spite of the tragedy.

\section{CONCLUSION}

The character of Umrao Jaan could have emerged as a tragic hero with reference to the plot of the novel. She is an artist, who writes poetry and ghazals, and is recognized as a strong skilful performer and a storyteller than a courtesan. The fact that she is a courtesan never changes, yet her songs are reflections of the tragedies of her past experiences, and therefore her songs are artistically designed filled with experience and pain. Her growth has been marked by her journey of self evolution from her disillusionments to her practical and realistic maturity on finally choosing to survive her tragedy instead of breaking down. The film could have ended with a strong message than with a sadistic approach. 


\section{REFERENCES}

Appanna, S. 2014. Women in Indian Cinema: Politician, Sex Symbol and Everything in between. Createspace Independent.

Bose, M. 2006. Bollywood: A History. Tempus Publication.

Byerly, C.M. and Ross, K. 2006. Women and Media: A Critical Introduction. Malden: Blackwell.

Chatterji, S.A. 1998. Subject Cinema, Object--Woman: A Study of the Portrayal of Women in Indian Cinema. Calcutta: Parumita Publications.

Hadi, M., Singh, K. and Husaini, M.A. 2005. Umrao Jan Ada: The Courtesan of Lucknow. Orient Paperbacks.

Hogan, P.C. 2008. Understanding Indian Movies: Culture, Cognition, And Cinematic Imagination. University of Texas Press.
Jain, J. and Rai, S. 2015. Films and Feminism: Essays in Indian Cinema. Jaipur: Rawat Publications.

Kazmi, F. 1999. The politics of India's Conventional Cinema: Imaging A Universe, Subverting A Multiverse. Sage.

Mulvey, L., Rose, R. and Lewis, M. 2016. Visual Pleasure and Narrative Cinema (1975). London: Afterall Books.

Mishra, V. 2002. Bollywood Cinema: Temples of Desire. Routledge.

Somaaya, B., Kothari, J. and Madangarli, S. 2012. Mother Maiden Mistress: Women in Hindi Cinema, 1950-2010. New Delhi: HarperCollins Publishers India \& India Today Group.

\section{Movies}

Directed by J.P. Dutta (2006). Umrao Jaan. Movie.

Directed by Muzaffar Ali (1981). Umrao Jaan. Movie. 